\title{
KEMANDIRIAN DAN MOTIVASI BELAJAR DALAM MENGGUNAKAN EDMODO TERHADAP HASIL BELAJAR SISWA
}

\author{
Ilham Ilahi ${ }^{1}$, Fahmi Rizal ${ }^{2}$, Dedy Irfan $^{3}$ \\ 1,2,3 Pendidikan Teknologi dan Kejuruan, Universitas Negeri Padang \\ Jalan Prof. Dr. Hamka, Air Tawar Barat, Padang Utara, Padang, Sumatra Barat \\ 1e-mail: ilhamilahi@hotmail.com
}

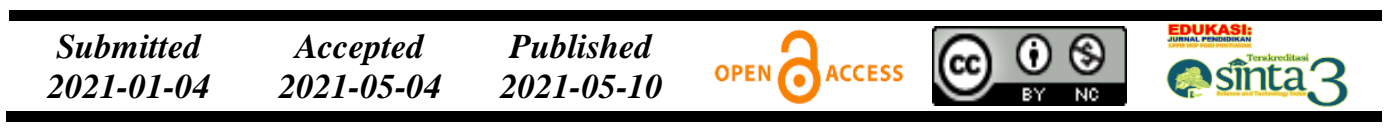

\begin{abstract}
Abstrak
Tujuan penelitian untuk membuktikan kontribusi kemandirian dan motivasi belajar dalam menggunakan Edmodo terhadap hasil belajar pada mata pelajaran Administrasi Infrastruktur Jaringan di SMK Negeri 4 Payakumbuh. Metode penelitian menggunakan korelasional. Populasi penelitian adalah siswa kelas XII TKJ SMK Negeri 4 Payakumbuh sebanyak 84 orang. Sampel penelitian yang digunakan adalah seluruh populasi. Data penelitian dikumpulkan dengan menggunakan instrumen angket untuk melihat kontribusi kemandirian dan motivasi belajar. Analisis data penelitian menggunakan statistik deskriptif, korelasi product moment, dan regresi ganda. Hasil penelitian menunjukkan bahwa dalam menggunakan Edmodo, kemandirian belajar berkontribusi positif terhadap hasil belajar; motivasi belajar berkontribusi positif terhadap hasil belajar; kemandirian dan motivasi belajar secara simultan berkontribusi positif terhadap hasil belajar pada mata pelajaran Administrasi Infrastruktur Jaringan di SMK Negeri 4 Payakumbuh.
\end{abstract}

Kata Kunci: kemandirian belajar; motivasi belajar; hasil belajar; Edmodo.

\begin{abstract}
The research objective was to prove the contribution of self-regulated learning and learning motivation in using Edmodo to learning outcomes in Network Infrastructure Administration subjects at SMK Negeri 4 Payakumbuh. The research method used correlational. The research population was 84 students of class XII TKJ SMK Negeri 4 Payakumbuh. The research sample used was the entire population. The research data were collected using a questionnaire instrument to see the contribution of independence and learning motivation. Analysis of research data used descriptive statistics, product moment correlation, and multiple regression. The results showed that in using Edmodo, students' self regulated learning contributed positively to learning outcomes; learning motivation contributes positively to learning outcomes; self-regulated learning and learning motivation simultaneously contribute positively to student learning outcomes in Network Infrastructure Administration subjects at SMK Negeri 4 Payakumbuh.
\end{abstract}

Keywords: self-regulated learning; motivation to learn; learning outcomes; Edmodo.

\section{PENDAHULUAN}

Indonesia mengalami masa pandemi COVID-19 yang tingkat penyebaran virusnya masih belum menunjukkan adanya angka penurunan. Dampak dari pandemi COVID-19 menjangkau hampir segala sektor kehidupan masyarakat. 
Setiap negara sudah melakukan penutupan terhadap sekolah, perguruan tinggi, dan lembaga pendidikan lainnya sampai batas waktu yang tidak ditentukan. Pemerintah Indonesia juga memutuskan untuk menutup semua fasilitas pendidikan untuk mengurangi kontak langsung dan berusaha mengurangi penyebaran COVID-19. Penutupan sementara fasilitas pendidikan menyebabkan proses pembelajaran dengan sistem tatap muka dihentikan dan digantikan dengan proses pembelajaran secara synchronous dan asynchronous. Kementerian Pendidikan dan Kebudayaan mengeluarkan Surat Edaran Nomor 4 Tahun 2020 tentang Pedoman Penyelenggaran Belajar Dari Rumah (BDR) di Masa Darurat Penyebaran COVID-19 dalam menghadapi proses pendidikan di masa pandemik yang bertujuan untuk memberikan kesempatan bagi siswa untuk memperoleh pendidikan selama masa darurat COVID-19; melindungi guru dan siswa dari dampak langsung COVID-19; dan mengurangi/mencegah diseminasi COVID-19 di sekolah (Depdikbud, 2020).

Perubahan metode pembelajaran dari metode konvensional (real) ke metode pembelajaran synchronous/asynchronous berbasis e-learning mengalami beberapa permasalahan yang menghambat efektivitas pembelajaran, seperti: (1) Adanya dependensi kompetensi guru dan siswa dalam penguasaan teknologi informasi; (2) Ketersediaan sarana dan prasarana yang belum akseptabel dan merata di setiap sekolah; (3) Akses internet yang terbatas dan tidak merata di berbagai lokasi; dan (4) Kesiapan pemerintah dalam alokasi anggaran pelaksanaan Pembelajaran Jarak Jauh (PJJ) (Aji, 2020). Siswa dan guru di Indonesia pada berbagai jenjang pendidikan belum terbiasa melakukan PJJ. Pandemi COVID-19 mengharuskan guru dan siswa beradaptasi secara cepat menggunakan teknologi informasi dalam pembelajaran (Mastura \& Santria, 2020). Sebelumnya, pembelajaran berbasis teknologi masih digunakan sebagai pelengkap. Penerapan PJJ dengan e-learning menuntut adanya kemandirian dan motivasi belajar siswa.

Kemandirian belajar (self regulated learning) adalah suatu aktivitas belajar yang bersumber dari siswa sendiri dengan mengikuti tujuan yang telah ditetapkan (Ananda, 2019). Kemandirian belajar adalah faktor penting yang menentukan efektivitas belajar siswa (Arista \& Kuswanto, 2018). Ciri-ciri siswa yang memiliki 
Edukasi: Jurnal Pendidikan, Volume 19 Nomor 1 Tahun 2021

Kemandirian dan Motivasi Belajar dalam Menggunakan Edmodo.......

Ilham Ilahi, Fahmi Rizal, Dedy Irfan

Halaman 75-89

sikap kemandirian belajar yaitu: (1) Memperlihatkan usaha yang kuat untuk menggapai prestasi; (2) Jarang melakukan sambat; (3) Optimis; dan (4) Memiliki keingintahuan yang kuat (Basri, 2006). Keberhasilan siswa dalam PJJ menggunakan Edmodo ditentukan oleh kemandirian belajar siswa. Kemandirian belajar ditunjukkan oleh sikap siswa, seperti memiliki kemampuan dalam menyelesaikan masalah, kemandirian dalam belajar, dan tidak tergantung kepada orang lain (Hidayat et al., 2020).

Motivasi belajar adalah daya gerak yang kuat bersumber dari jiwa siswa dalam melaksanakan proses belajar yang semangat, terarah, dan gigih untuk mencapai tujuan belajar yang telah ditentukan (Santrock, 2007). Siswa yang memiliki motivasi ditunjukkan oleh tingkah laku yang memiliki daya, tujuan, dan istikamah. Motivasi belajar disebabkan oleh beberapa faktor dan secara universal motivasi belajar dihasilkan oleh faktor intrinsik, yaitu faktor yang bersal dari internal siswa dan faktor ekstrinsik yang berasal dari eksternal siswa (Kompri, 2016). Selain faktor intrinsik dan ekstrinsik, ada beberapa faktor yang juga dapat memengaruhi motivasi belajar, seperti: (1) Penetapan cita-cita siswa; (2) Minat dan kemauan siswa; (3) Kondisi emosional siswa; (4) Kondisi ekosistem belajar siswa; dan (5) Upaya guru dalam mendidik (Sardiman, 2012). Untuk mengukur motivasi belajar ditentukan oleh indikator: (1) Memiliki tekad dan kemauan untuk sukses; (2) Memiliki motivasi dan kebutuhan dalam belajar; (3) Memiliki ambisi dan impian masa depan; (4) Mengharapkan hadiah dalam belajar; (5) Menciptakan aktivitas belajar yang menarik; dan (6) Dukungan ekosistem yang nyaman dalam belajar (Uno, 2006).

Penerapan PJJ dengan pemanfaatan e-learning pada penelitian yang dilakukan menggunakan Edmodo, aplikasi berbasis web, dan mobile yang merupakan jejaring sosial pendidikan yang menghubungkan para guru dan sekolah, serta terdapat fitur untuk saling berbagi konten pembelajaran di seluruh dunia. Edmodo adalah situs jejaring sosial pendidikan yang dirancang khusus untuk digunakan oleh guru dan siswa sebagai media kelas virtual yang dapat diakses di manapun dengan menggunakan koneksi internet. Nicolas Borg dan Jeff O’Hara tahun 2010 mendirikan Edmodo di Chicago, Amerika Serikat. Sebagai 
aplikasi kelas virtual, Edmodo memiliki fitur-fitur khusus, seperti kuis (evaluation), penugasan (assignment), polling, portofolio (gradebook), perpustakaan digital (library), penghargaan (award badges), dan memiliki kode akses bagi orang tua (parent code).

Keberhasilan pelaksanaan PJJ ditentukan oleh adanya kemandirian dan motivasi siswa dalam menggunakan aplikasi Edmodo. Berdasarkan hal tersebut, maka penelitian bertujuan untuk membuktikan adanya kontribusi antara kemandirian dan motivasi belajar siswa dalam menggunakan Edmodo terhadap hasil belajar siswa pada mata pelajaran Administrasi Infrastruktur Jaringan (AIJ) di SMK Negeri 4 Payakumbuh.

\section{METODE}

Penelitian menggunakan metode korelasional. Korelasional dipilih untuk melihat kontribusi antara kemandirian dan motivasi belajar siswa terhadap hasil belajar siswa. Populasi penelitian sebanyak 84 orang siswa kelas XII Teknik Komputer Jaringan (TKJ) di SMK Negeri 4 Payakumbuh pada mata pelajaran Administrasi Infrastruktur Jaringan (AIJ). Seluruh populasi menjadi sampel penelitian. Data penelitian dikumpulkan menggunakan instrumen angket untuk mengukur kemandirian dan motivasi belajar serta instrumen tes hasil belajar yang diberikan di akhir pembelajaran untuk mengukur hasil belajar siswa. Pengumpulan data penelitian dilakukan setelah pembelajaran daring menggunakan Edmodo sebanyak 6 kali pertemuan. Instrumen angket yang diberikan menggunakan skala pengukuran Likert. Untuk butir dengan pernyataan positif, skala yang digunakan yaitu: Selalu $=4$, Sering $=3$, Jarang $=2$, dan Tidak Pernah $=1$. Untuk butir dengan pernyataan negatif, skala yang digunakan yaitu: Selalu $=1$, Sering $=2$, Jarang $=3$, dan Tidak Pernah $=4$. Instrumen tes hasil belajar yang diberikan mengacu pada silabus pembelajaran berdasarkan Standar Kompetensi (SK) dan Kompetensi Dasar (KD). Instrumen tes digunakan untuk mengukur ranah kognitif (pengetahuan) dengan menggunakan tes dalam bentuk pilihan ganda.

Sebelum menyebarkan angket ke responden, terlebih dahulu dilakukan percobaan angket untuk mengukur validitas dan reliabilitas. Uji validitas dilakukan 
menggunakan formula korelasi product moment. Indikator angket penelitan yang digunakan untuk mengukur kemandirian dan motivasi belajar terlihat pada Tabel 1 dan Tabel 2, sedangkan indikator tes hasil belajar terlihat pada Tabel 3.

Tabel 1 Indikator dan Kisi-Kisi Angket Kemandirian Belajar

\begin{tabular}{clc}
\hline Variabel & \multicolumn{1}{c}{ Indikator } & Butir Angket \\
\hline & Percaya diri & 5 \\
& Giat dalam belajar & 5 \\
Kemandirian & Istikamah dalam belajar & 5 \\
belajar & Kewajiban & 5 \\
& Tidak tergantung pada orang lain & 5 \\
& Inisiatif & 5 \\
\hline
\end{tabular}

Tabel 2 Indikator dan Kisi-Kisi Angket Motivasi Belajar

\begin{tabular}{clc}
\hline Variabel & \multicolumn{1}{c}{ Indikator } & Jumlah Butir \\
\hline \multirow{5}{*}{ Motivasi } & Memiliki tekad yang kuat untuk berhasil & 5 \\
belajar & Memiliki keinginan untuk belajar & 5 \\
& Memiliki impian masa depan & 5 \\
& Mengharapkan penghargaan terhadap belajar & 5 \\
& Dukungan ekosistem belajar yang nyaman & 5 \\
\hline
\end{tabular}

Tabel 3 Indikator dan Kisi-Kisi Instrumen Tes Hasil Belajar

\begin{tabular}{clc}
\hline Variabel & \multicolumn{1}{c}{ Kompetensi Dasar } & Jumlah Soal \\
\hline \multirow{4}{*}{ Hasil belajar } & 3.3. Memahami Proses Routing & 5 \\
& 3.4. Mengevaluasi Routing Statis & 5 \\
& 3.5. Mengevaluasi Routing Dinamis & 5 \\
& 3.6. Mengevaluasi Internet Gateway & 5 \\
\hline
\end{tabular}

Data penelitian dianalisis menggunakan pendekatan statistik deskriptif inferensial melalui uji korelasi-regresi ganda menggunakan bantuan software SPSS 22. Data penelitian yang telah terkumpul disusun dalam bentuk gambaran rentangan data statistik dengan bantuan tabel distribusi frekuensi variabel. Penentuan ukuran rentangan dan kelas interval data penelitian menggunakan aturan Sturgess seperti yang terlihat pada rumus (1) (Sudjana, 1996).

$$
K=1+3,3 \log n
$$

Keterangan: $\mathrm{K}$ adalah jumlah kelas interval; $\mathrm{n}$ adalah jumlah responden.

Setelah diperoleh data rentangan pada tabel frekuensi, kemudian disusun tabel berdasarkan kategori yang terlihat pada Tabel 4 (Arikunto, 2010). 
Tabel 4 Kategori Skor Variabel

\begin{tabular}{cc}
\hline Kategori & Rumus \\
\hline Sangat Tinggi & $\mathrm{N}>\mathrm{Me}+\mathrm{SD}$ \\
Tinggi & $\mathrm{Me}+\mathrm{SD} \geq \mathrm{N}>\mathrm{Me}$ \\
Rendah & $\mathrm{M} \geq \mathrm{X}>\mathrm{Me}-\mathrm{SD}$ \\
Sangat Rendah & $\mathrm{Me}-\mathrm{SD} \geq \mathrm{N}$ \\
\hline
\end{tabular}

Keterangan: N adalah perolehan skor; Me adalah Median; SD adalah Standar Deviasi.

Uji persyaratan analisis digunakan sebelum melakukan analisis data penelitian. Adapun tes persyaratan analisis yang digunakan yaitu uji normalitas, linieritas, dan multikolinieritas. Uji normalitas dan linieritas ditentukan berdasarkan parameter apabila nilai sig. lebih besar dari (>) 0,05, maka data dikatakan berdistribusi normal dan linier. Sedangkan uji multikolinieritas ditentukan apabila nilai VIF lebih kecil dari (<) 10, maka tidak terjadi multikolinieritas. Pengujian hipotesis dilakukan dengan kriteria jika $r_{\text {hitung }}$ lebih kecil dari atau sama dengan $(\leq) \mathrm{r}_{\text {tabel, }}$, maka tolak $\mathrm{H}_{\mathrm{o}}$ yang artinya tidak signifikan; sedangkan jika $r_{\text {hitung }}$ lebih besar dari atau sama dengan $(\geq) r_{\text {tabel, }}$ maka terima $H_{o}$ yang artinya signifikan. Taraf signifikan $(\alpha)=0,05$. Untuk mengukur nilai dari dampak yang ditimbulkan oleh varibel independen terhadap variabel dependen dapat menggunakan formula koefisien determinan seperti yang terlihat pada rumus (2) (Riduwan, 2008).

$$
K P=r^{2} \times 100 \%
$$

Keterangan: KP adalah nilai Koefisien Determinan; $r$ adalah nilai koefisien korelasi.

Uji korelasi digunakan untuk melihat kontribusi kemandirian dan motivasi terhadap hasil belajar secara simultan dan parsial. Variabel independen dan dependen disebut berhubungan jika $r_{\text {hitung }}$ lebih besar dari $(>) r_{\text {tabel. }}$ Analisis korelasi dilakukan dengan bantuan aplikasi SPSS.

\section{HASIL DAN PEMBAHASAN}

Berdasarkan uji normalitas yang dilakukan, diperoleh hasil Asymp. Sig. untuk variabel kemandirian sebesar 0,2; motivasi sebesar 0,2; dan hasil belajar 
Edukasi: Jurnal Pendidikan, Volume 19 Nomor 1 Tahun 2021

Kemandirian dan Motivasi Belajar dalam Menggunakan Edmodo.......

Ilham Ilahi, Fahmi Rizal, Dedy Irfan

Halaman 75-89

sebesar 0,91. Nilai Asymp .Sig yang dihasilkan lebih besar dari (>) 0,05. Hal tersebut berarti data penelitian berdistribusi normal. Hasil uji normalitas terlihat pada Tabel 5.

Tabel 5 Hasil Uji Normalitas

\begin{tabular}{ccc}
\hline Variabel & p-Hitung & Keputusan \\
\hline Kemandirian & 0,200 & Normal \\
Motivasi & 0,200 & Normal \\
Hasil Belajar & 0,91 & Normal \\
\hline
\end{tabular}

Hasil uji linieritas menunjukkan bahwa antara kemandirian dan hasil belajar memiliki korelasi linier dengan nilai sig. 0,009 lebih kecil dari $(<)$ 0,05. Motivasi memiliki korelasi linier dengan hasil belajar dengan nilai sig. 0,003 lebih kecil dari (<) 0,05. Hasil uji linieritas terlihat pada Tabel 6 .

Tabel 6 Hasil Uji Linieritas

\begin{tabular}{cccc}
\hline Hubungan & F $_{\text {hitung }}$ & Sig. & Kesimpulan \\
\hline Kemandirian dengan hasil belajar & 1,480 & 0,009 & Linier \\
Motivasi dengan hasil belajar & 1,968 & 0,003 & Linier \\
\hline
\end{tabular}

Hasil uji multikolinieritas menunjukkan bahwa nilai tolerance sebesar 0,677 lebih kecil dari $(<) 1$ dan nilai VIF sebesar 1,476 lebih kecil dari $(<) 10$. Berdasarkan hasil perhitungan tersebut, disimpulkan bahwa tidak terdapat masalah multikolinieritas antara kemandirian dan motivasi. Hasil uji multikolinieritas terlihat pada Tabel 7.

Tabel 7 Hasil Uji Multikolinieritas

\begin{tabular}{cccc}
\hline \multirow{2}{*}{ Koefisien Korelasi } & \multicolumn{2}{c}{ Collinearity Statistic } & \multirow{2}{*}{ Kesimpulan } \\
\cline { 2 - 3 } & Tolerance & VIF & \\
\hline $\begin{array}{c}\text { Kemandirian dengan } \\
\text { motivasi }\end{array}$ & 0,677 & 1,476 & $\begin{array}{c}\text { Tidak terjadi } \\
\text { multikolineritas }\end{array}$ \\
\hline
\end{tabular}

Korelasi product moment digunakan untuk uji hipotesis penelitian. Hasil pengujian tersebut terlihat pada Tabel 8 .

Tabel 8 Hasil Uji Korelasi Product Moment

\begin{tabular}{ccc}
\hline Korelasi & $\mathbf{r}_{\text {hitung }}$ & $\mathbf{r}_{\text {tabel }}$ \\
\hline Kemandirian terhadap hasil belajar & 0,565 & 0,1807 \\
Motivasi terhadap hasil belajar & 0,599 & 0,1807 \\
\hline
\end{tabular}

Hasil pengujian hipotesis pertama diperoleh nilai $r_{\text {hitung }}=0,565$ lebih besar dari $(>) r_{\text {tabel }}=0,1807$. Berdasarkan hasil tersebut, maka disimpulkan terdapat 
kontribusi kemandirian terhadap hasil belajar dengan taraf signifikansi $5 \%$. Kemudian untuk hipotesis kedua diperoleh nilai $r_{\text {hitung }}=0,599$ lebih besar dari $(>)$ $\mathrm{r}_{\text {tabel }}=0,1807$, sehingga dapat disimpulkan bahwa terdapat kontribusi motivasi terhadap hasil belajar.

Hasil perhitungan regresi ganda diperoleh nilai sumbangan relatif untuk variabel kemandirian sebesar 43,30\% dan motivasi sebesar 54,48\%. Hal tersebut berati kemandirian belajar menggunakan Edmodo berpengaruh terhadap hasil belajar sebesar 43,40\%. Temuan tersebut mendukung hasil penelitian terdahulu yang menunjukkan bahwa hasil belajar dipengaruhi oleh kemandirian belajar (Herpanus et al., 2020; Siagian et al., 2020; Abdullah \& Silalahi, 2019; Bramantha, 2019; Darma et al., 2016). Edmodo berperan dalam media PJJ antara siswa dan guru. Dengan Edmodo siswa dituntut agar cepat beradaptasi menggunakan aplikasi dan siswa semakin mandiri dalam belajar dengan pola pembelajaran on-demand.

Proses pembelajaran daring menggunakan Edmodo dapat meningkatkan kemandirian belajar siswa. Kemandirian belajar siswa ditunjukkan dengan sikap siswa yang tidak bergantung kepada siapapun dan menetapkan sendiri kompetensikompetensi belajarnya dan mempunyai dorongan, ide, dan perjuangan untuk mengejar prestasi (Basri, 2006). Kemandirian belajar memberikan kebebasan kepada siswa untuk menentukan gaya belajar yang dapat mengembangkan kreativitas, motivasi, dan minat belajar siswa secara mandiri (Mulyono, 2017).

Sumbangan relatif untuk variabel motivasi adalah sebesar $54,48 \%$ yang artinya motivasi berpengaruh terhadap hasil belajar sebesar 54,48\%. Motivasi belajar merupakan faktor yang mampu meningkatkan hasil belajar siswa/ mahasiswa (Syachtiyani \& Trisnawati, 2021; Jumarniati \& Anas, 2019; Hidayat \& Dediansyah, 2018; Fatmawati, 2015; Hidayat et al., 2015; Koriaty \& Nurbani, 2015). Temuan penelitian mendukung hasil penelitian terdahulu yang menunjukkan bahwa penggunaan media e-learning dapat meningkatkan motivasi belajar mahasiswa (Aurora \& Effendi, 2019). Motivasi belajar merupakan daya dorong dan kemauan yang bersumber dari internal siswa untuk mencapai tujuan belajar dengan terarah dan bertahan lama (Santrock, 2007). 
Edukasi: Jurnal Pendidikan, Volume 19 Nomor 1 Tahun 2021

Kemandirian dan Motivasi Belajar dalam Menggunakan Edmodo.......

Ilham Ilahi, Fahmi Rizal, Dedy Irfan

Halaman 75-89

Motivasi belajar menggerakkan siswa untuk melakukan aktivitas belajar, baik dengan kesadaran sendiri ataupun tanpa disadari dalam meraih tujuan tertentu (Andriani \& Rasto, 2019). Siswa yang mempunyai motivasi belajar akan memperlihatkan kemauan dan tekad untuk belajar, menetapkan impian masa depan, memiliki keinginan yang kuat untuk berhasil, mampu menciptakan kegiatan belajar yang menyenangkan serta didukung oleh kondisi belajar yang kondusif (Uno, 2007). Semakin tinggi motivasi belajar siswa, maka akan meningkatkan pencapaian hasil belajar (Ningrat et al., 2018).

Temuan penelitian menunjukkan bahwa motivasi memiliki kontribusi yang lebih besar dalam memengaruhi hasil belajar dibandingkan dengan kemandirian. Guru berperan untuk mendorong dan memberikan semangat kepada siswa agar dapat meningkatkan motivasi belajar. Dorongan dari guru kepada siswa untuk meningkatkan motivasi belajar memberikan dampak yang signifikan terhadap hasil belajar (Saputra et al., 2018). Edmodo berperan sebagai media untuk merangsang dan meningkatkan motivasi belajar siswa. Siswa yang aktif dalam melakukan aktivitas pembelajaran daring menggunakan Edmodo adalah siswa yang memiliki motivasi belajar yang tinggi. Hal tersebut terlihat dari aktivitas dan kegiatan pembelajaran yang disusun oleh guru pada pembelajaran menggunakan Edmodo.

Kemandirian dan motivasi belajar secara simultan berkontribusi terhadap hasi belajar (Ansel, 2020; Fitriani, 2020; Halim \& Rahma, 2020; Salmah et al., 2020; Saputri, et al., 2020; Silea, 2020; Tampubolon, 2020). Indikator kemandirian dan motivasi belajar keduanya saling memiliki kaitan. Kemandirian belajar akan berbanding lurus dengan motivasi belajar siswa. Siswa yang mempunyai motivasi belajar yang baik akan terus berusaha meraih tujuannya, salah satunya dengan meningkatkan kemandirian belajar. Penggunaan Edmodo sebagai media e-learning dapat meningkatkan kemandirian dan motivasi siswa yang berdampak pada peningkatan hasil belajar siswa. Edmodo terbukti efektif dapat meningkatkan kemandirian dan motivasi belajar siswa. Siswa yang memiliki kemandirian dan motivasi belajar yang tinggi akan mendapatkan hasil belajar yang baik.

Penggunaan Edmodo sebagai media PJJ (e-learning) dengan dukungan fiturfitur sebagai kelas virtual sangat membantu guru dalam merancang pembelajaran. 
Edmodo dapat menumbuhkan sikap kemandirian dan meningkatkan motivasi belajar siswa yang berkontribusi terhadap hasil belajar (Rifqah, 2018; Rosyidah et al., 2018; Ramadhani, 2016). Namun demikian, temuan penelitian bertentangan dengan hasil penelitian terdahulu yang menyatakan bahwa siswa/mahasiswa belum siap untuk mengikuti PJJ karena kurangnya kemandirian, motivasi, dan kebiasaan (Hidayat et al., 2020).

Salah satu permasalahan dalam PJJ adalah keterbatasan kompetensi guru dan siswa dalam menggunakan aplikasi e-learning (Halal, 2020). PJJ yang belum memiliki format baku menuntut kreativitas guru untuk merancang pembelajaran yang menarik sehingga minat siswa untuk belajar dapat bertambah. Dengan sikap kemandirian belajar yang dimiliki siswa, maka siswa akan memiliki inisiatif untuk menguasai kompetensi tersebut. Namun demikian, terjadi kesenjangan antara siswa dan guru. Hal tersebut karena siswa berada pada kelompok digital native yang memiliki kemampuan untuk adaptasi dengan teknologi digital yang sangat cepat, sedangkan guru termasuk pada kategori digital migrant (Rahmawati et al., 2019). Kesenjangan tersebut berdampak terhadap ketertarikan siswa dalam melaksanakan PJJ yang bergantung pada kreativitas guru dalam menyusun pembelajaran berbasis digital.

\section{SIMPULAN}

Berdasarkan hasil penelitian, disimpulkan bahwa kemandirian dalam menggunakan Edmodo berkontribusi positif dan berpengaruh terhadap hasil belajar siswa. Motivasi dalam menggunakan Edmodo berkontribusi positif dan berpengaruh terhadap hasil belajar siswa. Hasil analisis data menunjukkan adanya hubungan antara kemandirian dan motivasi belajar secara simultan terhadap hasil belajar siswa kelas XII TKJ pada mata pelajaran AIJ di SMK Negeri 4 Payakumbuh.

\section{DAFTAR PUSTAKA}

Abdullah, R., \& Silalahi, J. (2019). The independence learning and learning outcomes of mathematical analysis of student at Civil Engineering 
Departement, Universitas Negeri Padang. Journal of Physics (ICTVT2019), 1456(2020), 1-8.

Aji, R. H. S. (2020). Dampak COVID-19 pada pendidikan di Indonesia: Sekolah, keterampilan, dan proses pembelajaran. SALAM: Jurnal Sosial dan Budaya Syar'i, 7(5), 395-402. https://doi.org/10.15408/sjsbs.v7i5.15314.

Ananda, R. (2019). The effect of learning strategies and learning independence on learning outcomes in learning evaluation subject. International Journal of Language, Research and Education Studies (IJLRES), 3(3), 340-350.

Andriani, R., \& Rasto. (2019). Motivasi belajar sebagai determinan hasil belajar siswa. Jurnal Pendidikan Manajemen Perkantoran, 4(1), 80-86. https://doi.org/10.17509/jpm.v4i1.14958.

Ansel, M. (2020). Hubungan motivasi berprestasi dan kemandirian belajar peserta didik SDN Ende 5 Kabupaten Ende. Jurnal Cakrawala Pendas, 6(1), 75-83. http://dx.doi.org/10.31949/jcp.v6i1.1859.

Arikunto, S. (2010). Prosedur penelitian suatu pendekatan praktek. Jakarta: Rineka Aksara.

Arista, S. F., \& Kuswanto, H. (2018). Virtual physics laboratory application based on Android smartphone to improve learning independence and conceptual understanding. International Journal of Intruction, 11(1), 1-16. https://doi.org/10.12973/iji.2018.1111a.

Aurora, A., \& Effendi, H. (2019). Pengaruh penggunaan media pembelajaran elearning terhadap motivasi belajar mahasiswa di Universitas Negeri Padang. Jurnal Teknik Elektro dan Vokasional (JTEV), 5(2), 11-16. https://doi.org/10.24036/jtev.v5i2.105133.

Basri, H. (2006). Pengaruh pola asuh orang tua terhadap kemandirian siswa dalam belajar. Skripsi: Universitas Negeri Sebelas Maret. Tidak dipublikasikan.

Bramantha, H. (2019). Pengaruh kemandirian belajar terhadap hasil belajar siswa. MADROSATUNA : Jurnal Pendidikan Guru Madrasah Ibtidaiyah, 2(1), 2128. https://doi.org/10.47971/mjpgmi.v2i1.63. 
Darma, Y., Firdaus, M., \& Haryadi, R. (2016). Hubungan kemandirian belajar terhadap kemampuan pemecahan masalah matematis mahasiswa calon guru Matematika. Edukasi: Jurnal Pendidikan, 14(1), 169-178. http://dx.doi.org/10.31571/edukasi.v14i1.294.

Depdikbud. (2020). Surat Edaran Nomor 4 Tahun 2020 tentang Pedoman Penyelenggaran Belajar Dari Rumah (BDR) di Masa Darurat COVID-19. Jakarta: Depdikbud.

Fatmawati, E. (2015). Pengaruh pola asuh orang tua, lingkungan, gaya belajar, dan motivasi terhadap prestasi belajar mahasiswa. Jurnal Pendidikan Informatika dan Sains, 4(1), 40-59. http://dx.doi.org/10.31571/ saintek.v4i1.5.

Fitriani, W., Haryanto, H., \& Atmojo, S. (2020). Motivasi berprestasi dan kemandirian belajar mahasiswa saat pembelajaran daring. Jurnal Pendidikan: Teori, Penelitian, dan Pengembangan, 5(6), 828-834. http://dx.doi.org/10.17977/jptpp.v5i6.13639.

Halim, S., \& Rahma. (2020). Pengaruh lingkungan belajar, motivasi belajar, dan kemandirian belajar terhadap hasil belajar Matematika siswa kelas XI IPA SMAN 9 Pangkep. Mandalika Mathematics and Educations Journal, 2(2), 102-109. http://dx.doi.org/10.29303/jm.v2i2.1777.

Herpanus, Fitrianingrum, E., \& Bantut, A. (2020). Hubungan kemandirian belajar terhadap hasil belajar siswa pada mata pelajaran Bahasa Indonesia kelas VIII SMP N 02 Tempunak. Jurnal Kansasi : Jurnal Pendidikan Bahasa dan Sastra Indonesia, 5(1), 1-8. https://doi.org/10.31932/jpbs.v5i1.734.

Hidayat, R. D., Rohaya, A., Nadine, F., \& Ramadhan, H. (2020). Kemandirian belajar peserta didik dalam pembelajaran daring pada masa pandemi COVID-19. Jurnal Perspektif Ilmu Pendidikan, 34(2), 147-154. https://doi.org/10.21009/PIP.342.9.

Hidayat, S., \& Dediansyah, A. (2018). Hubungan motivasi dengan hasil pembelajaran Sejarah pada siswa kelas X SMA Negeri 8 Pontianak. Sosial Horizon: Jurnal Pendidikan Sosial, 5(1), 65-75. http://dx.doi.org/ 10.31571/sosial.v5i1.858. 
Hidayat, S., Siswandi, \& Bahri, S. (2015). Hubungan antara motivasi belajar dengan hasil belajar mahasiswa Prodi Sejarah semester 3 IKIP PGRI Pontianak TA 2014/2015. Edukasi: Jurnal Pendidikan, 13(1), 73-82. http://dx.doi.org/10.31571/edukasi.v13i1.21.

Jumarniati, J., \& Anas, A. (2019). Pengaruh motivasi belajar dan aktivitas belajar terhadap hasil belajar mahasiswa Program Studi PGSD. Cokroaminoto Journal of Primary Education, 2(2), 41-47. https://doi.org/10.30605/ cjpe.222019.113.

Kompri. (2016). Motivasi pembelajaran perspektif guru dan siswa. Bandung: Remaja Rosdakarya.

Koriaty, S., \& Nurbani. (2015). Pengaruh gaya belajar dan motivasi terhadap prestasi belajar mahasiswa pada matakuliah Organisasi dan Arsitektur Komputer. Jurnal Pendidikan Informatika dan Sains, 4(2), 287-296. http://dx.doi.org/10.31571/saintek.v4i2.77.

Mastura, \& Santaria, J. (2020). Dampak pandemi COVID-19 terhadap proses pengajaran bagi guru dan siswa. Jurnal Studi Guru dan Pembelajaran, 3(2), 289-295. https://doi.org/10.30605/jsgp.3.2.2020.293.

Mulyono, D. (2017). The influence of learning model and learning independence on mathematics learning outcomes by controlling student's early ability. International Electronic Journal of Mathematics Education (IEJME), 12(3), 670-709.

Ningrat, P. S., Tegeh, M., \& Sumantri, M. (2018). Kontribusi gaya belajar dan motivasi belajar terhadap hasil belajar Bahasa Indonesia. Jurnal Ilmiah Sekolah Dasar, 2(3), 257-268. http://dx.doi.org/10.23887/jisd.v2i3.16140.

Rahmawati, D., Kesa, D. D., Suciati, P., \& Lusia, A. (2019). Karakteristik generasi digital natives dalam lingkungan digital. Studi kasus Kampung Digital Vokasi UI. Prosiding Seminar Nasional Teknologi Terapan Inovasi dan Rekayasa (SNT2IR) Tahun 2019.

Ramadhani, D. (2016). Pengaruh penggunaan e-learning berbasis Edmodo terhadap kemandirian, motivasi, dan hasil belajar pada materi Sistem 
Gerak SMA Nasional Plus Cinta Budaya Medan. Tesis: Universitas Negeri Medan. Tidak dipublikasikan.

Riduwan. (2008). Belajar mudah penelitian untuk guru, karyawan dan penelitian pemula. Bandung: Alfabet.

Rifqah. (2018). Meningkatkan sikap kemandirian dan hasil belajar siswa pada mata pelajaran PPKn melalui penerapan media Edmodo kelas XI A Multimedia SMK Negeri 1 Banjarmasin. Lentera: Jurnal Pendidikan, 13(2), 76-86.

Rosyidah, Kartini, T., \& Kantun, S. (2018). Penggunaan media Edmodo untuk meningkatkan motivasi dan hasil belajar siswa. Jurnal Pendidikan Ekonomi, 13(2), 78-84. http://dx.doi.org/10.19184/jpe.v13i2.10878.

Salmah, A., Relita, D. T., \& Suriyanti, Y. (2020). Hubungan kemandirian belajar dan motivasi berprestasi dengan hasil belajar mata pelajaran Ekonomi siswa kelas XI SMAN 01 Belimbing. JURKAMI: Jurnal Pendidikan Ekonomi, 5(1), 45-54. https://doi.org/10.31932/jpe.v5i1.726.

Santrock, J. W. (2007). Psikologi pendidikan edisi kedua. Terjemahan Tri Wibowo, B. S. Jakarta: Prenada Media Group Purwanto.

Saputra, D. H., Ismel, F., \& Andrizal. (2018). Pengaruh motivasi terhadap hasil belajar SMK. Jurnal Inovasi Vokasional dan Tenologi (INVOTEK), 18(1), 25-30. https://doi.org/10.24036/invotek.v18i1.168.

Saputri, I., Edy, S., \& Midjan, M. (2020). Pengaruh motivasi dan kemandirian belajar (self regulated learning) terhadap hasil belajar Matematika pada peserta didik kelas VII di SMP Negeri I Kebomas. DIDAKTIKA : Jurnal Pemikiran Pendidikan, 26(2), 14-23. https://doi:10.30587/ didaktika.v26i2.1467.

Sardiman, A. M. (2012). Interaksi dan motivasi belajar mengajar. Jakarta: Rajawali Pers.

Siagian, H., Pangaribuan, J. J., \& Silaban, P. J. (2020). Pengaruh kemandirian belajar terhadap hasil belajar Matematika siswa di sekolah dasar. Jurnal Basicedu, 4(4), 1363-1369. https://doi.org/10.31004/basicedu.v4i4.528. 
Silea, W. O. S. N. A. (2020). Pengaruh perhatian orang tua, kemandirian dan motivasi belajar terhadap hasil belajar mata pelajaran IPS siswa SMP Negeri 14 Baubau. Jurnal Penelitian dan Pendidikan IPS, 12(2), 42-46.

Sudjana. (1996). Metode Statistika. Bandung: Sinar Baru Algasindo.

Syachtiyani, W. R., \& Trisnawati, N. (2021). Analisis motivasi belajar dan hasil belajar siswa di masa pandemi COVID-19. Prima Magistra: Jurnal Ilmiah Kependidikan, 2(1), 90-101. https://doi.org/10.37478/jpm.v2i1.878.

Tampubolon, B. (2020). Motivasi belajar dan tingkat belajar mandiri dalam kaitannya dengan prestasi belajar mahasiswa. Jurnal PIPSI (Jurnal Pendidikan Ilmu Pengetahuan Sosial Indonesia), 5(2), 34-41. http://dx.doi.org/10.26737/jpipsi.v5i2.1920.

Uno, H. B. (2007). Profesi kependidikan problema, solusi, dan reformasi pendidikan di Indonesia. Jakarta: Bumi Aksara.

Uno, H. B. (2006). Teori motivasi dan pengukurannya analisis di bidang pendidikan. Jakarta: Bumi Aksara. 